\title{
Stakeholder Orientation and Corporate Reputation: A Quantitative Study on US Companies*
}

\author{
Francesco Perrini ${ }^{* *}$, Clodia Vurro ${ }^{* * *}$
}

\begin{abstract}
Intangibles, such as corporate reputation, are increasingly considered the major source for value creation and company success. Given the importance of having a strong corporate reputation, new strategic and operational approaches are emerging to manage it, such as stakeholder-based practices. Relying on extensive data over a period of six years, this study develops and tests the relationship between stakeholder orientation and corporate reputation. Results show that the sign of the relationship is positive and statistically significant, supporting the view that a stakeholder-oriented disclosure strategy can be associated with a series of bottom-line benefits such as an improvement in corporate reputation.
\end{abstract}

Keywords: Corporate Social Responsibility; Stakeholder Orientation; CSR Disclosure; Corporate Reputation

\section{Global Markets, Corporate Reputation and Stakeholder Management}

In the search for new sources of competitive advantage in a global economy, companies have rapidly adopted flexible production methods, made of combinations of specialization, outsourcing and contracting with multiple suppliers to serve geographically dispersed markets, thus leading to the creation of global value chains (Brondoni 2010). Political economy, public opinion and managerial literature have started to be concerned with the developmental consequences of value chain disaggregation, pointing out to the need for and competitive benefits of voluntarily integrating social and environmental issues into corporate strategy and business operations (Perrini, Vurro 2010). It is not by chance that responsible behavior is consistently emerging as a compelling factor in the public's evaluation of reputation (Corniani 2010; Schnietz, Epstein 2005). As a consequence, in an increasingly competitive market, managers are confronting themselves with balancing financial viability with solid corporate social responsibility (CSR, hereafter) commitment (Lambin 2009).

\footnotetext{
* The Authors: F. Perrini $\S 1$, C. Vurro $\S \S 2,3,4$

** Full Professor of Management, L. Bocconi University-Milan (francesco.perrini@ unibocconi.it)

*** Lecturer of Management, L. Bocconi University-Milan (clodia.vurro@unibocconi.it)
}

Edited by: ISTEI - University of Milan-Bicocca

ISSN: 1593-0319

Perrini Francesco, Vurro Clodia (2013) Stakeholder Orientation and Corporate Reputation: A Quantitative Study on US Companies, Symphonya. Emerging Issues in Management (symphonya.unimib.it), n. 1, pp. $53-65$. 
Socially responsible approaches become even more relevant as long as dramatic challenges emerge in the business environment, fueled by new market developments, political events, technological advancements. These global trends present opportunities for growth and profit along with challenges and risks that can jeopardize the competitive survival of a firm, provoking important questions about the very nature of the corporation's dominant role in society and its long-term future potentially affecting the economic activity at large (Andersen, Schroder 2010).

The sources of this challenges can be found in the complexity, the degree of uncertainty in the business environment, and market dynamism, three aspects shaping the overall risk in the market (Miller, Shamsie 1999). More specifically, complexity is mainly due to proliferation of stakeholders affected by and affecting business decision making. Companies tend to interact with more and more heterogeneous actors. As a result they find it increasingly difficult to adapt to the numerous and often contradictory societal expectations, making it necessary to develop new skills, competencies and attitudes to cope with complex operating environments. In this context, effective stakeholder management becomes key to foresee changing expectations and to detect conflicts when they are not yet threatening the firm. Uncertainty is related to managerial perceptions of the general business environment or one of its components, as unpredictable (Dess, Beard 1984). Uncertainty is specific to a given firm, industry or region and it is shaped by economic, political and technological determinants. An uncertain environment is one in which it is difficult to identify, measure or predict critical variables, increasing the risk of failure for organizational responses and making it difficult to compute costs and probabilities associated with alternative options (Milliken 1987). Finally, environmental dynamism refers to the rate of change, absence of patterns and unpredictability of the environment. This implies the occurrence of rapid, frequent and complex changes in the external environment in which companies exist (Dyer, Ross 2008).

These considerations underline the importance of an effective response to stakeholders in order to safeguard reputation, interpreted as meeting stakeholders' reasonable expectations of an organization's performance and behavior (Atkins et al. 2006; Zucchella 2007).

Literature agrees on recognizing the strategic role of CSR initiatives in order to protect corporate reputation (Vanhamme, Grobben 2009) that is not an add-on, but a key aspect of business performance: by aligning operational practices with stakeholders' expectations and adopting a longer-term view of business, CSR initiatives offer a route to competitive differentiation (Perrini et al. 2011).

In this sense, studies have shown that positive evaluations about a company's CSR activities stimulate stakeholders' expectations about the future behavior of the company (Surroca et al. 2010), enhancing the generation of a good reputation. This confirms that if companies want to succeed in improving their reputation, they need to activate an effective management of stakeholder relationship. If managing relations with stakeholders is necessary for enhancing reputation and value maximization, then it is reasonable to expect the development of stakeholder orientation to be positively related to firm reputation (Benson, Davidson 2010). 
Based on recent advancements in the literature on the competitive case for CSR, our study aims at testing the effectiveness of adopting a stakeholder approach in managing corporate reputation (Schnietz, Epstein 2005). According to Barney's resource-based view of the firm (1991), stakeholder orientation appears as a strategy that allows global firms to differentiate and outperform their rivals achieving business sustainability and stakeholder satisfaction. Building better relations with stakeholders like employees, customers, suppliers and communities (Freeman 1984), stakeholder orientation is expected to enhance corporate reputation by increasing the trustworthiness of a firm as a valuable partner (Brondoni 2003).

The study proceeds as follows: we begin by developing a theoretical model to guide empirical analysis, based on a set of questions and challenges for theory and practice on how to put effective corporate reputation management in place. Then sample selection procedure and variable definitions are reported, followed by descriptive statistics and main results. A discussion of the results, implications and limitations of this study is then provided in the final sections.

\section{The Impact of Stakeholder Orientation on Corporate Reputation Through CSR Disclosure}

With the renewed expectations of corporate conduct within a global stakeholder society the design and implementation of CSR disclosure procedures has definitely become the cornerstone of the CSR movement (Salvioni, Bosetti 2006), on the wave of the growing awareness, shared by both research and practice, of the competitive benefits accruing to firms integrating wider economic, environmental, and societal concerns into their ongoing operations and interaction with stakeholders, on a voluntary basis and beyond legal prescriptions (Vurro, Perrini 2011).

Representing the basis for understanding and tracking social and environmental impacts, through the creation of a platform for stakeholder dialogue, effective CSR disclosure is intended as a natural step in the path to stakeholder-related performance improvement (Salvioni 2002). In fact, reporting is essential to inform internal decisions, enabling companies to identify strengths and weaknesses across the whole corporate responsibility spectrum in order to be aware of the extent to which valuable long-term relationships and assets have been created. In addition to strengthening internal systems and decision making, effective measuring through CSR-related reports helps companies managing external relationships as well, attracting stakeholders who favor socially responsible business and have the power to reward it.

In other words, CSR disclosure and reporting represent the most direct result of the tendency by firms to show their social performance to stakeholders. Moreover, if as Fombrun and Van Riel (1997) assert, reputation is "a collective representation of a firm's past actions and results that describes the firms' ability to deliver valued outcomes to multiple stakeholders", then CSR disclosure and reporting may be viewed as managerial tools to manage the relations with stakeholders and consequently, have the potential to create reputation effects. If this statement is 
true, then the more an organization engages with its stakeholders, the stronger the need to be accountable toward them by disclosing CSR-related information and the larger the impact on reputation.

Literature and managerial practice converge on the following conclusion. The volume of disclosure should matter in predicting performance related to the stakeholder orientation initiatives implemented by the firm. If companies want to succeed in improving stakeholder management they have to measure and communicate their commitment to CSR systematically. An increase in the quantity of information disclosed through CSR reports - what we call disclosure depth represents a stronger commitment to CSR and stakeholders (Hummels, Timmer 2004) and thus leads to better reputation.

Thus we hypothesize:

HP1: The higher the depth of CSR disclosure by firm $i$ at time t, the stronger the impact on corporate reputation at time $t+1$

If CSR disclosure is considered a good measure of current social performance that both provides information about areas of future improvement, and helps to build a strategy for future objectives and actions, then aggregate measures miss the opportunity to distinguish between companies that differ in the extent to which they include different stakeholders and stakeholder-related areas. In fact the path to sustainability is completed only if a company actively engages not only with primary stakeholders but also with secondary actors, listening to them and taking responsibility for providing transparent, consistent and relevant communications in line with their legitimate expectations (Vurro et al. 2010).

In this sense, the more firms are able to extend their social responsibilities over a broad set of stakeholders and related issues - what we call disclosure breadth - the higher their social performance.

Thus we hypothesize:

HP2: The larger the breadth of CSR disclosure by firm $i$ at time t, the stronger the impact on corporate reputation at time $t+1$

Management and strategy research have long emphasized the internal stakeholders such as employees, customers, and stockholders, that is, those who have a direct stake in the firm's activities and operations. However, increasingly secondary stakeholders (e.g., community activists, public institutions, media, and other nongovernmental organizations), that is, those that do not have a formal contractual bond with the firm or direct legal authority over it, are increasing research attention to their ability to pressure the firms (Eesley, Lenox 2006), imposing either operational costs (e.g., public-relations expenses) or losses in terms of intangible resources (e.g., trust and reputation). However, what distinguishes stakeholder theory is its reliance on the crucial assumption that the interests of all legitimate stakeholders have to be considered equally, because of their intrinsic value (Donaldson, Preston 1995). In other words, stakeholder theory is driven by the morals and values of an organization. This assumption defines the normative foundation of stakeholder theory, that is, each stakeholder is considered "for its 
own sake and not merely because of its ability to further the interests of some other groups, such as the shareowners" (Donaldson, Preston 1995). However, the above assumption neither implies that stakeholders behave in the same way toward each firm, nor that all firms treat relationships the same way. The instrumental and descriptive traditions of stakeholder theory are focused on these issues, the former on the link between responsiveness to stakeholders and success or performance (Wood 1991), and the latter investigating the way firms and stakeholders concretely interact.

Accordingly, regardless of disclosure volume, truly socially responsible firms will be able to address a broad set of stakeholders equally. The ability to extend corporate attention to all stakeholders is hallmark to a firm's success as a responsible player. As a result, given the same disclosure volume and coverage, a firm that concentrates on a single or few stakeholder categories is not necessarily similar to a firm that can distribute its attention more equally to a broader set of stakeholders. Thus we hypothesize:

HP3: The less homogeneous the distribution of CSR disclosure by firm $i$ at time $t$ among stakeholders, the weaker the impact on corporate reputation at time $t+1$.

\section{Methodology and Empirical Evidence}

Sample selection: The purpose of our paper is to assess the extent to which stakeholder orientation initiatives through CSR disclosure are predictors of reputation, taking into consideration the level of risk in the business environment.

The target population corresponds to US firms belonging to the S\&P 500. The sample $^{1}$ was selected taking into consideration the criteria of a constant reporting on CSR issues. Merging the Fortune Magazine's annual ranking of the World's Most Admired companies for the dependent variable (i.e., reputation) with CSR reports for the independent variables (i.e., disclosure breadth, depth and concentration), we yielded a final sample size of 249 firm over a six-year time period, ranging between 2004 and 2009. Analyses were thus performed on an unbalanced longitudinal dataset of 630 firm-year observations. The panel structure of the dataset allowed us to control for the cumulative nature of corporate reputation, thus overcoming the limit of considering it a yearly measure.

CSR reports were collected through CorporateRegister.com, the global corporate responsibility resources website ${ }^{2}$ and then analyzed through content analysis, a methodology used in the social sciences for studying the content of communication. Annual reports on CSR were chosen as the document to be analyzed in order to find the firms' disclosure practices addressed to stakeholders, since as a source of information for the interested public, they are the most important documents of public knowledge and the most used internationally (Adams 2004).

Dependent variable: As discussed, reputation is a prized, and highly vulnerable, corporate asset. An overview of academic literature and business publications on 
corporate reputation reveals a lack of cohesiveness in the terminology and measurement. Moreover, reputation is largely subjective in nature and not necessarily based in whole or in part upon the objective evaluation of certain aspects of an organization's behavior (Burke et al. 2011). Hence, corporate reputation is a relative and dynamic concept and may be difficult to measure it. The most popular methods to measure reputation are the social rankings, or rankings of firms based on the opinions expressed by the general public on the components of reputation. In fact investors may regard ratings by a third party (e.g. Fortune magazine) as trustworthier than firms' own disclosures in annual reports.

Consequently, we measured corporate reputation based on the Fortune Magazine's annual ranking of the World's Most Admired companies. Since 1997, FORTUNE, in partnership with Hay Group, annually identifies and ranks the Most Admired Companies. In order to develop the index, companies are sorted by industry in order to select the 15 largest for each international industry and the 10 largest for each U.S. industry. For those companies on the Most Admired list, a maximum of 10 top executives and seven directors (outside board members) per company are surveyed on nine attributes identified as crucial in terms of shaping corporate reputation. The attributes are: ability to attract and retain talented people, quality of management, social responsibility to the community and the environment, innovativeness, quality of products or services, wise use of corporate assets, financial soundness, long-term investment value, effectiveness in doing business globally. In our research, in order to assess the reputation score of a firm, we supposed that the effects of stakeholder initiatives influence the reputation of the firm one-year later, in $\mathrm{t}+1$. The time lag is justified by the fact that the publics become aware of these initiatives only when the company discloses these details outside, usually after the fact has happened.

Independed variables: To explore the causal relationships between disclosure structure and performance, an aggregate measure of CSP was required. Consistent with previous literature, measures of stakeholder orientation were based on a content analysis of the CSR reports released by the companies included in the sample. We relied on a recording instrument to record the typology and amount of CSR disclosure and standardize data collection. We developed the recording instrument based on a previous comparative analysis of the standard reporting frameworks currently available. Relying on the data collected through the content analysis, we differentiated among three measures representative of the structure of CSR disclosure: CSR disclosure depth measured as the total volume of disclosure provided by each company in the sample over the three-year period; CSR disclosure breadth indicating the variety of stakeholder-related themes included in the CSR reports released by each companies for each year; CSR disclosure concentration as the extent to which company stakeholders are evenly or unevenly covered in the reports ${ }^{3}$.

Control variables: In this study, control variables were included to ensure that any relations found between reputation, stakeholder orientation and business environment, are not a result of other confounding variables. In fact, stakeholder orientation and hence voluntary disclosure on this issue is not uniform but depends 
on different dimensions that could be coded as organizational and environmental, according to their dependence on internal or external factors.

Among the organizational affecting factors, size has been suggested to be a factor that affects both reputation and CSR initiatives. Previous research shows that size has either a positive or a U-shaped effect on CSR projects. In addition size may influence the resources dedicated by the firm to responding to its stakeholders' concerns. Moreover larger organizations may be subject to greater scrutiny by the media and other stakeholders. It is therefore expected that large companies are more likely to conduct socially responsible activities. We controlled for organization size through the natural logarithm of employees (Rueda-Manzanares et al. 2007).

The Global Reporting Initiative (GRI) ${ }^{4}$ released its Sustainability Reporting Guidelines in order to encourage comparability, materiality and rigor with reporting. On the one hand it allows comparison between CSR strategies, on the other hand it makes too standardized the sustainability reports. Consequently we introduced the use of GRI guidelines in reporting as a control variable in order to differentiate between standardized and not standardized CSR reports.

Firm profitability, measured by return on assets (ROA), is used to control for the impact of economic performance on the company's social disclosures. Considering the costs involved in becoming socially responsible, economic performance is an important factor in determining whether social responsibility issues will be on the priority list. The same regressions were performed by controlling for return on equity, and results didn't changed. Since significance was higher by controlling for ROA, we kept this indicator as a measure for firm profitability.

The environmental affecting factors are represented by two sets of dummy variables, one related to the year of the reports and one to the industries the firm belongs to. Given the longitudinal nature of the dataset, the dummy variable for the years is included to pick up any effects specific to the years in the analysis. In addition previous literature has indicated a need to control for industry (Waddock, Graves 1997) in order to ensure that differences in the level of disclosure and in the consequent impact on reputation across the sample are not merely an effect of industry differences. Industry has been operationalized using the standard 2-digit SIC code.

Estimation procedure: We relied on STATA to perform a pooled OLS estimation regression. In order to check the homoskedasticity assumption and find the presence of heteroskedasticity, we used the Cook-Weisberg and the White test statistics (Cook, Weisberg 1983). Then, in order to correct for heteroskedasticity, we used a robust-cluster estimator of the standard errors of the variables included in the regressions. The robust-cluster variance estimator is a variant of the HuberWhite robust estimator, which provides correct standard errors in the presence of any pattern of heteroskedasticity. It also remains valid and provides correct coverage in the presence of any pattern of correlation among errors within units. This estimator allowed relaxing the assumption of independence of errors in the regression. Since in the model it is used a pooled time-series approach (the same company analyzed over six different years), repeated observations may create correlated error terms and inflate t-statistics without using this correction. In fact, 
the robust-standard errors are unaffected by the presence of unmeasured firmspecific factors causing correlation among errors of observations for the same firms, or for that matter any other form of within-unit error correlation. Thus, the robust-cluster estimator produces correct standard errors even when the observations are correlated within clusters (STATA 2005).

Results support the hypotheses stated. Corporate reputation grows and strengthens, as a reflection of the firm's orientation to stakeholders.

With 5\% significance depth, breadth and concentration are significant in explaining the dependent variable, reputation at $t+1$. Moreover also the positive or negative impact is in line with expectations. In particular, the weighted volume of disclosure regarding stakeholder's related issues has a positive effect on reputation as predicted by hypothesis $1(\beta=0.02, \mathrm{p}<.01)$; in addition, the more themes a firm covers in its nonfinancial report, the higher its reputation in the next year, as predicted by hypothesis $2(\beta=0.04, \mathrm{p}<.05)$; finally, as predicted by hypothesis 3 $(\beta=-0.26, p<.05)$, disclosing more but in favor of a limited set of stakeholders is more likely to decrease the reputation of the firm in the next year (please, refer appendix 1 for the regression table).

Overall the most significant variable in this regression is breadth because 42,74 $\%$ of the reputation increase is due to the covering of a broad set of stakeholders and related issues.

It is important to underline that the size of a company is always significant in explaining the relation between stakeholder orientation and reputation. This means that big companies have more incentives to address stakeholders and, consequently, enhance reputation through these strategic initiatives.

With regard to the control variables, performance is highly significant and has a positive impact in relation to depth and breadth. Standard is not a significant variable, meaning that the use of a standard in reporting is not relevant to assess the reputation of a firm.

\section{Emerging Issues and Conclusions}

The results of the analysis show an overall positive and significant relationship between stakeholder orientation and corporate reputation, as stated in the hypotheses. In general, if correctly implemented, a stakeholder approach functions as a feedback system for the purpose of forming or revisiting the core identity of the firm to avoid unveiling the gap between the firm's organizational reality and its reputation.

In particular, analyzing the three variables used to assess stakeholder orientation (disclosure depth, breadth and concentration), the higher the quantity of information on stakeholders disclosed through CSR reports (disclosure depth), the higher the contribution to corporate reputation. This confirms that the visibility of stakeholder initiatives in CSR reports is an important component in order to make such activities known and verifiable by the company's stakeholders.

Supporting hypothesis 2, the analysis confirms that firms able to extend their social responsibility over a broad set of stakeholders and related issues (i.e., disclosure breadth) have a better chance to increase reputation. Consequently, 
firms that are strong social performers, able to adapt to different stakeholders, are able to strengthen and consolidate their corporate reputation (de Quevedo Puente et al. 2007). This means that a thorough analysis and an understanding of the current and potential stakeholders' expectations should form a core element of the strategic planning process in order to safeguard reputation. This is sometime described as "outside-in thinking" (Atkins et al. 2006), that is a company's ability to view itself from the many different perspectives that stakeholders have of it. In fact a company wishing to manage its reputation or/and achieve superior reputation, needs to understand the range of its stakeholders' expectations, and seek to achieve alignment between all these expectations and what the company plans to do.

These findings support the theoretical claims that CSR cannot be understood separately from the dependence relationships between companies and their social context, such that detection and scanning of, and response to the social demand become fundamental to achieving social legitimacy, greater social acceptance, prestige (Garriga, Melé 2004), and hence to strengthen corporate reputation.

Moreover, supporting hypothesis 3, findings point to the benefits associated with distributing disclosure efforts equally among stakeholders. Given a certain amount of disclosure volume and coverage, firms that concentrate on few stakeholder categories cannot be associated with those able to satisfy the information needs of a more comprehensive set of stakeholders and hence to influence corporate reputation.

To sum up, since corporate reputations are representations of public opinion about a firm and such opinions depend on a firm's success in meeting the expectations of those stakeholders, demonstrating a high degree of stakeholder orientation is a signal that the firm will behave in accordance with stakeholders' expectations (Brammer, Pavelin 2006). The firm's reputation will consequently be augmented (Donaldson, Preston 1995).

Researchers have studied intangibles such has corporate reputation (Burke et al. 2011) and its link to different dimensions of corporate social responsibility.

This study contributes to that scholarly knowledge on reputation evidencing how it is positively related to the implementation of a stakeholder approach. These results have reinforced the stakeholder theory of the firm by highlighting the importance of its contribution in the development of intangible and valuable assets, such as corporate reputation. By aligning operational practices with stakeholder expectations and adopting a longer view of the business, it is consequently an investment in reputation (Diermeier 2011).

Based on such emerging evidence, more extensive studies are needed to explore the mechanisms linking corporate reputation to stakeholder orientation and to determine whether or not this relationship holds consistently over time. It is important to posit the timing in the relationship, since it would be valuable to investigate and to ascertain how long it takes for the impact of stakeholder orientation on corporate reputation to be revealed, since in this research we supposed a time lag of one year.

In addition, it would be worthwhile to replicate the same model using the performance of the firm, measured by its Return on asset, as a dependent variable because, as shown in the analysis, it affects corporate reputation, in turn influencing the investments in stakeholder-oriented initiatives. Anyway, other 
measures of performance could be more suitable than accounting measures that, such as ROA, do not capture the long-term value of the company or value created for shareholders (Hillman, Keim 2001). Lastly, a finer-grained analysis of the stakeholder orientation and of the relevant stakeholders can be a better predictor of superior reputation.

\section{Bibliography}

Adams Carol A. (2004) The Ethical, Social and Environmental Reporting-Performance Portrayal Gap, Accounting, Auditing \& Accountability Journal, vol. 17, n. 5, pp. 731-757. http://dx.doi.org/10.1108/09513570410567791

Andersen Torben Juul, Schroder Peter Winther (2010) Strategic Risk Management Practice, Cambridge University Press, Cambridge, UK.

Atkins Derek, Bates Ian, Drennan Lynn (2006) Reputational risk: A Question of Trust, Loupe Solutions, London, UK.

Barney Jay (1991) Firm Resources and Sustained Competitive Advantage, Journal of Management, vol. 17, n. 1, pp. 99-120. http://dx.doi.org/10.1177/014920639101700108

Benson Bradley W., Davidson Wallace N. (2010) The Relation Between Stakeholder Management, Firm Value and CEO Compensation: A Test of Enlightened Value Maximization, Financial Management, vol. 39, n. 3, pp. 929-963. http://dx.doi.org/10.1111/j.1755-053X.2010.01100.x

Brammer Stephen J., Pavelin Stephen (2006) Corporate Reputation and Social Performance: The Importance of Fit, Journal of Management Studies, vol. 43, n. 3, pp. 435-455. http://dx.doi.org/10.1111/j.1467-6486.2006.00597.x

Brondoni Silvio M. (2003) Network Culture, Performance \& Corporate Responsibility, Symphonya. Emerging Issues in Management (symphonya.unimib.it), n. 1, pp. 8-24. http://dx.doi.org/10.4468/2003.1.02brondoni

Brondoni Silvio M. (2010) Intangibles, Global Networks and Corporate Social Responsibility, Symphonya. Emerging Issues in Management (symphonya.unimib.it), n. 2, pp. 6-24. http://dx.doi.org/10.4468/2010.2.02brondoni

Burke Ronald J., Martin Graeme, Cooper Cary L. (2011) Corporate Reputation: Managing Opportunities and Threats, Gower, Farnham.

Cook R. Dennis, Weisberg Sanford (1983) Diagnostic for Heteroskedasticity in Regression, Biometrika, vol. 70, n. 1, pp. 1-10. http://dx.doi.org/10.1093/biomet/70.1.1

Corniani Margherita (2010) The Cost of Managing Intangibles in Global Markets, Symphonya. Emerging Issues in Management (symphonya.unimib.it), n. 2, pp. 52-66. http://dx.doi.org/10.4468/2010.2.05corniani

de Quevedo Puente Esther, de la Fuente Sabatè Juan Manuel, Delgrado-Garcia Juan Bautista (2007) Corporate Social Performance and Corporate Reputation: Two Interwoven Perspectives, Corporate Reputation Review, vol. 10, n.1, pp. 60-72. http://dx.doi.org/10.1057/palgrave.crr.1550038

Dess Gregory G., Beard Donald W. (1984) Dimensions of Organizational Task Environments, Administrative Science Quarterly, vol. 29, pp. 52-73. http://dx.doi.org/10.2307/2393080 
Diermeier Daniel (2011) Reputation Rules: Strategies for Building Your Company's Most Valuable Asset, McGraw-Hill, USA.

Donaldson Thomas, Preston Lee E. (1995) The Stakeholder Theory af The Corporation: Concepts, Evidence, and Implications, Academy of Management Review, vol. 20, n. 1, pp. 65-91. http://dx.doi.org/10.5465/AMR.1995.9503271992

Dyer Linda M., Ross Christopher (2008) Seeking Advice in a Dynamic and Complex Business Environment: Impact on the Success of Small Firms, Journal of Developmental Entrepreneurship, vol. 13, n. 2, pp. 133-149. http://dx.doi.org/10.1142/S1084946708000892

Eesley Charles, Lenox Michael J. (2006) Firm Responses to Secondary Stakeholder Action, Strategic Management Journal, vol. 27, n. 8, pp. 765-781. http://dx.doi.org/10.1002/smj.536

Fombrun Charles J., Van Riel Cees B. M. (1997) The Reputational Landscape, Corporate Reputation Review, vol. 1, n. 1/2, pp. 5-13.

Freeman R. Edward (1984) Strategic Management: A Stakeholder Approach, (Pitman, Boston).

Garriga Elisabet, Melé Domènec (2004) Corporate Social Responsibility Theories: Mapping the Territory, Journal of Business Ethics, vol. 53, n. 1, pp. 51-71.

Hillman Amy J., Keim Gerald D. (2001) Shareholder Value, Stakeholder Management, and Social Issues: What's The Bottom Line?, Strategic Management Journal, vol. 22, pp. 125-139. http://dx.doi.org/10.1002/1097-0266(200101)22:2<125::AID-SMJ150>3.0.CO;2-H

Hummels Harry, Timmer Diederik (2004) Investors in Need of Social, Ethical, and Environmental Information, Journal of Business Ethics, vol. 52, n. 1, pp. 73-84. http://dx.doi.org/10.1023/B:BUSI.0000033108.20321.f5

Lambin Jean-Jacques (2009) Capitalism and Sustainable Development, Symphonya: Emerging Issues in Management (symphonya.unimib.it), n. 2, pp. 1-6. http://dx.doi.org/10.4468/2009.2.021ambin

Miller Danny, Shamsie Jamal (1999) Strategic Responses to Three Kinds of Uncertainty: Product Line Simplicity at the Hollywood Film Studios, Journal of Management, vol. 25, n. 1, pp. 97116. http://dx.doi.org/10.1177/014920639902500105

Milliken Frances J. (1987) Three Types of Perceived Uncertainty about the Environment: State, Effect, and Response Uncertainty, Academy of Management Review, vol. 12, n. 1, pp. 133-143.

Perrini Francesco, Russo Angeloantonio, Tencati Antonio, Vurro Clodia (2011) Deconstructing the Relationship between Social and Financial Performance, Journal of Business Ethics, vol. 102, $\mathrm{n}$. 1, pp. 59-76. http://dx.doi.org/10.1007/s10551-011-1194-1

Perrini Francesco, Vurro Clodia (2010) Corporate sustainability, Intangible Assets and Competitive Advantage, Symphonya. Emerging Issues in Management (symphonya.unimib.it), n. 2, pp. 1-8. http://dx.doi.org/10.4468/2010.2.03perrini.vurro

Rueda-Manzanares Antonio, Aragòn-Correa J.Alberto, Sharma Sanjay (2007) The Influence of Stakeholders on the Environmental Strategy of Service Firms: The Moderating Effects of Complexity, Uncertainty And Munificence, British Journal of Management, vol. 19, n. 2, pp. 185-203. http://dx.doi.org/10.1111/j.1467-8551.2007.00538.x

Salvioni Daniela M. (2002) Transparency Culture and Financial Communication, Symphonya. Emerging Issues in Management (symphonya.unimib.it), n. 2, pp. 1-12. http://dx.doi.org/10.4468/2002.2.04salvioni 
Salvioni Daniela M., Bosetti Luisa (2006) Corporate Governance Report and Stakeholder View, Symphonya. Emerging Issues in Management (symphonya.unimib.it), n. 1, pp. 1-25. http://dx.doi.org/10.4468/2006.1.03salvioni.bosetti

Schnietz Karen E., Epstein Marc J. (2005) Exploring the Financial Value of a Reputation for Corporate Social Responsibility during a Crisis, Corporate Reputation Review, vol. 7, n. 4, pp. 327-345. http://dx.doi.org/10.1057/palgrave.crr.1540230

STATA (2005) Stata User's Guide (STATA Release 9), Stata Press.

Surroca Jordi, Tribò Jorep A., Waddock Sandra (2010) Corporate Responsibility and Financial Performance: The Role of Intangible Resources, Strategic Management Journal, vol. 31, n. 5, pp. 463-490. http://dx.doi.org/10.1002/smj.820

Vanhamme Joëlle, Grobben Bas (2009) “Too Good To Be True!”. The Effectiveness of CSR History in Countering Negative Publicity, Journal of Business Ethics, vol. 85, Supplement 2, pp. 273-283. http://dx.doi.org/10.1007/s10551-008-9731-2

Vurro Clodia, Dacin M. Tina, Perrini Francesco (2010) Institutional Antecedents of Partnering for Social Change: How Institutional Logics Shape Cross-Sector Social Partnerships, Journal of Business Ethics, vol. 94, Supplement 1, pp. 39-53. http://dx.doi.org/10.1108/14720701111159280

Vurro Clodia, Perrini Francesco (2011) Making the Most of Corporate Social Responsibility Reporting: Disclosure Structure and its Impact on Performance, Corporate Governance: The International Journal of Business in Society, vol. 11, n. 4, pp. 459-474. http://dx.doi.org/10.1108/14720701111159280

Waddock Sandra, Graves Samuel B. (1997) The Corporate Social Performance - Financial Performance Link, Strategic Management Journal, vol. 18, n. 4, pp. 303-319. http://dx.doi.org/10.1002/(SICI)1097-0266(199704)18:4<303::AID-SMJ869>3.0.CO;2-G

Wood Donna J. (1991) Corporate Social Performance Revisited, Academy of Management Review, vol. 16, n. 4, pp. 691-718. http://www.jstor.org/stable/258977

Zucchella Antonella (2007) Network Social Responsibility, Symphonya: Emerging Issues in Management (symphonya.unimib.it), n. 2, pp. 64-71. http://dx.doi.org/10.4468/2007.2.07zucchella

\section{Notes}

${ }^{1}$ The S\&P 500 is a free-float capitalization-weighted index, published since 1957, of the prices of 500 large-cap common stocks actively traded in the United States.

2 This website hosts the world's most comprehensive directory of corporate non-financial reporting, profiling over 26,000 reports.

${ }^{3}$ For further details on how the content analysis procedure was develop, as well as independent variable computed please refer to Vurro, Perrini 2011.

4 The Global Reporting Initiative (GRI) is a network-based organization that pioneered the world's most widely used sustainability reporting framework. 
(C) SYMPHONYA Emerging Issues in Management, n. 1, 2013

symphonya.unimib.it

Appendix 1: Regression Results for Reputation as a Dependent Variable

\begin{tabular}{|c|c|c|c|c|c|c|}
\hline \multirow[b]{2}{*}{ Reputation $_{t+1}$} & \multicolumn{2}{|c|}{ Hypothesis 1} & \multicolumn{2}{|c|}{ Hypothesis 2} & \multicolumn{2}{|c|}{ Hypothesis 3} \\
\hline & Coefficient & Standard Error & Coefficient & Standard Error & Coefficient & Standard Error \\
\hline Depth & $.0020^{*}$ & .0010 & & & & \\
\hline Breadth & & & $.0427 * *$ & .0287 & & \\
\hline Concentration & & & & & $-.2601 * *$ & .3992 \\
\hline Constant & 5.1268 & .5510 & 4.9814 & .5453 & 5.2052 & .9077 \\
\hline Log-size & $.1503 * * *$ & .0540 & $.1602 * * *$ & .0544 & $.1710^{* *}$ & .0724 \\
\hline Standard & -.0359 & .1147 & -.0086 & .1087 & -.0142 & .1424 \\
\hline Performance & $1.9452 * * *$ & .5889 & $1.9613 * * *$ & 6057 & -.0018 & .0018 \\
\hline D- year 1 & Omitted & - & Omitted & - & Omitted & - \\
\hline D- year 2 & -.0313 & .0771 & -.0279 & .0778 & .0053 & .0833 \\
\hline D- year 3 & $.1767^{*}$ & .0987 & $.2290 * *$ & .0926 & $.3532 * * *$ & .1201 \\
\hline D- year 4 & -.0737 & .1014 & -.0249 & .0954 & .1807 & .1269 \\
\hline D- year 5 & $-.3765^{* * *}$ & .1055 & $-.3376 * * *$ & .0970 & $-.2781 *$ & .1656 \\
\hline D- year 6 & Omitted & - & Omitted & - & Omitted & - \\
\hline D- industry 1 & Omitted & - & Omitted & - & -.2960 & .4469 \\
\hline D- industry 2 & $-.3989 * *$ & .1901 & $-.4298 * *$ & .1875 & -.2367 & .3817 \\
\hline D- industry 3 & -.2269 & .1753 & -.2453 & .1756 & -.2421 & .3882 \\
\hline D- industry 4 & & .1757 & .0237 & .1746 & -.0893 & .3915 \\
\hline D- industry 5 & $-.4030 *$ & .2276 & $-.4173 *$ & .2298 & -.4773 & .4035 \\
\hline D- industry 6 & -.2628 & .1905 & -.2677 & .1898 & -.4714 & .3935 \\
\hline D- industry 7 & -.1776 & .2827 & -.1949 & .2804 & Omitted & - \\
\hline D- industry 8 & Omitted & - & Omitted & - & Omitted & - \\
\hline N. observation & \multicolumn{2}{|c|}{616} & \multicolumn{2}{|c|}{616} & \multicolumn{2}{|c|}{415} \\
\hline R-squared & \multicolumn{2}{|c|}{0.1845} & \multicolumn{2}{|c|}{0.1808} & \multicolumn{2}{|c|}{0.1957} \\
\hline Prob $>F$ & \multicolumn{2}{|c|}{0.0000} & \multicolumn{2}{|c|}{0.0000} & \multicolumn{2}{|c|}{0.0004} \\
\hline
\end{tabular}

